\title{
Are Immigrant Remittance Flows a Source of Capital for Development?
}

\author{
RALPH CHAMI, CONNEL FULLENKAMP, and SAMIR JAHJAH*
}

There is a general presumption in the literature and among policymakers that immigrant remittances play the same role in economic development as foreign direct investment and other capital flows, but this is an open question. We develop a model of remittances based on the economics of the family that implies that remittances are not profit-driven, but are compensatory transfers, and should have a negative correlation with GDP growth. This is in contrast to the positive correlation of profit-driven capital flows with GDP growth. We test this implication of our model using a new panel data set on remittances and find a robust negative correlation between remittances and GDP growth. This indicates that remittances may not be intended to serve as a source of capital for economic development. [JEL D64, D82, F22]

he role of immigrant remittances in economic development continues to be an important issue for researchers and policymakers. Both groups are attracted to immigrant remittances because they represent a substantial flow of financial resources, predominantly from developed economies to developing economies. For example, Buch and others (2002) estimate that total remittances (plus compensation of employees) averaged $\$ 81$ billion per year during the

*Ralph Chami is a deputy division chief in the IMF Institute. Connel Fullenkamp is Visiting Professor, Department of Economics, Duke University. Samir Jahjah is an economist in the IMF Institute. The authors would like to thank Adolfo Barajas, Roland Daumont, Samir El-Khouri, Andrew Feltenstein, Mohsin S. Khan, Tala Khartabil, Philip Lane, Miguel Messmacher, Peter Montiel, Mika Saito, Sunil Sharma, Ilhyock Shim, Gabriel Srour, and the participants at the Fourth Annual IMF Research Conference for their thoughtful comments and suggestions. 
1990s. Our own estimates, containing remittances only, peaked at over \$59 billion per year in the mid-1990s. It is difficult to see these numbers and not think that remittances could be an important tool for economic development. Indeed, a common theme motivating much of the research on immigrant remittances is that if they can be better understood, then perhaps they can either be shown to promote development on their own, or they can be channeled into productive investment by wise policies. This sentiment appears in papers by Straubhaar (1986), Elbadawi and Rocha (1992), El-Sakka and McNabb (1999), Buch and others (2002) and others.

But whether remittances truly represent flows of investment capital is an open question. It merits careful investigation, because of the significant implications for development policy. There are several ways to approach this question, but a rather simple and direct way is to examine whether remittances behave in the same way as other capital flows. In particular, we expect that remittances would have a positive correlation with output growth if they are like other capital flows.

In this paper, we model the causes of remittances in order to find a simple test of whether remittances behave like other capital flows. Our model is built on two aspects of remittances that have important implications for the modeling strategy. First, despite their aggregate size, remittances are made up of millions of individual, private, nonmarket income transfers. Therefore, the appropriate foundation for our model is the economics of such transfers. This literature originates with Becker's (1974) economics of the family, and indeed many researchers in migration and remittances now use the family as the basic unit of analysis. Second, the remitter and the recipient of the transfer are separated by long distances-often, oceans-for long periods. Thus, remittance transfers take place under conditions of asymmetric information.

We specify a model of remittances that incorporates the features suggested by the preceding two observations. We motivate remittances by appealing to the economics of the family. There are many ways to incorporate the economics of the family into the model, and we discuss them in more detail below. In our model, the relationship between migrant and family is characterized by altruism, so that the utility of the migrant depends on the utility of his family members at home. This implies that remittances will be sent in order to help the family avoid shortfalls created by a poor economy or simple bad luck. In other words, the model implies that remittances are compensatory transfers, which should fluctuate countercyclically.

Thus, our model leads to one main testable implication: remittances are compensatory and hence countercyclical. Rather than test this implication on a single country, we collect a panel of aggregate data on remittances that includes up to 113 countries over (up to) 29 years, and use panel estimation methods to take advantage of cross-sectional variation. This is the first study to use panel methods to analyze remittances. We find that the data confirms the countercyclical nature of remittances, which is consistent with the model's implication that remittances are compensatory transfers. These results imply that remittances do not act like a source of capital for economic development. 


\section{The Literature on Causes of Remittances}

The theoretical literature on remittances is large, in the sense that many researchers have at least informally suggested theories describing their role in the economy in order to motivate an empirical exercise. But most theories offered have tended to follow a common theme. Early approaches to the theory of remittances identified and described various costs and benefits to remitting. Russell (1986) summarizes these. Stark and Bloom (1985) realized that the appropriate unit of analysis in migration and remittance questions is the family, because the entire family is sharing, and trading off, the costs and benefits of remitting. Therefore, the recent theoretical literature on the role of remittances has focused on, and can be categorized by, the possible roles that the family or family relationships can play in shaping remittance choices.

Many economists, even before the advent of the New Economics of Labor Migration (NELM), acknowledged that family ties in the form of mutual caring are probably a prime motivation for remitting. The earliest papers on remittances, such as Johnson and Whitelaw (1974), mention altruistic motivations for remittances. Lucas and Stark (1985, p. 902) write that "Certainly the most obvious motive for remitting is pure altruism - the care of a migrant for those left behind. Indeed, this appears to be the single notion underlying much of the remittance literature." They go on to specify an altruistic utility function in which the migrant's utility includes the consumptions of the other members of the household. This, however, is the maximum extent of formalization of the altruistic model of remittances.

Instead, more recent theories have focused on the idea that there can be selfinterested reasons for remitting as well, which nevertheless center on the family. These self-interested theories of remittances are still based on the family because they view the family as a business or as a nexus of contracts that enables the members to enter into Pareto-improving arrangements. Several different types of businesses or contracts are possible, which has led to various self-interested models of remittances. In the initial paper of this sort, Lucas and Stark (1985) suggest that migrants may have investments that need to be tended while they are away, so they will use other family members as their agents. The remittances sent by the migrant are used to care for the migrant's interests, but they also contain some compensation for the agents.

Another potential role for the family is that of financial intermediary. Stark (1991), as well as Agarwal and Horowitz (2002) and Gubert (2002), suggest that the family can function as an insurance company that provides members with protection against income shocks by diversifying the sources of income. On the other hand, Poirine (1997) and Ilahi and Jafarey (1999) model the family as a bank that finances migration for some members. The borrowers remit funds in order to repay the loans, which are put toward more loans to further the interests of other individual family members.

But these arrangements may not be as self-interested as they first appear. Altruism has been shown to motivate risk-sharing behavior, and Chami and Fischer (1996) show that altruism can be a mechanism by which independent agents find 
partners with whom to enter into risk-sharing arrangements. ${ }^{1}$ Even if the remittance arrangements are truly self-interested, the self-enforcing mechanism on which they depend may actually be altruism - that is, the migrant will live up to her obligations because she cares about the family members who are the counterparties to the agreement. This idea is explored in Stark and Lucas (1988). Thus, although the motivations to remit are doubtlessly complex, altruism between family members appears to be a good benchmark to use when modeling the interaction of causes and effects of remittances.

Now we turn to the empirical literature on immigrant remittances. Elbadawi and Rocha (1992) present a detailed review and insightful analysis of the literature on the causes of immigrant remittances, which applies well to all remittances. They divide this literature into two main strands: the "endogenous migration" approach, and the "portfolio" approach. The endogenous migration approach is based on the economics of the family, as discussed above, which includes but is not limited to motivations based on altruism. The portfolio approach isolates the decision to remit from the decision to migrate, and likewise avoids issues of family ties. In this view, the migrant earns income and decides how to allocate savings between host country assets and home country assets. Remittances are a result of deciding to invest in home country assets. The portfolio view, therefore, is an informal theory of remittances that supports the view that remittances behave like other capital flows.

The endogenous migration approach to remittances implies that the set of variables most useful for determining the level of remittances includes economic data that describes the economic situations facing the migrant and the family, and demographic data that describes the strength of family ties or the existence of other family arrangements. For example, the length of the migrant's stay in the host country is thought to weaken the desire of the migrant to remit because the migrant comes to regard herself more and more as a permanent migrant who has formed her own independent household. In the portfolio view, the rates of return on various assets, or return differentials, should influence remittances. The variables used in such studies include interest rate differentials on comparable deposit accounts offered in the host and home (labor-sending) countries, incentive interest rates offered on home country deposits, black market exchange premium (if any), the return on real estate in the home country, inflation rates, and other returns. In addition, political risk and uncertainty may also affect the decision to remit.

In practice, few papers that perform empirical estimations of remittance determination use only the endogenous migration approach or the portfolio approach. ${ }^{2}$ For example, Wahba (1991) divides remittances into "fixed" remittances, which go toward family support, and "discretionary" remittances, which are investment flows. The fixed remittances depend on family characteristics like size and income level, and therefore may be explained by the endogenous migration view. ${ }^{3}$ In gen-

\footnotetext{
${ }^{1}$ On the role of the family in risk sharing and income pooling, see Abel and Kotlikoff (1988), Altonji, Hayashi, and Kotlikoff (1992), and Townsend (1994), among others.

${ }^{2}$ Straubhaar (1986) is a paper that relies only on the portfolio approach.

${ }^{3}$ Nothing in the portfolio approach necessarily contradicts the endogenous migration approach. One may think of the portfolio view in terms of a "selfish" immigrant who only cares about the earnings on her own savings, which she intends to keep for herself. See, for example, Glytsos (1988).
} 
eral, empirical analyses include some demographic variables such as the stock of migrants in the host country (or family characteristics in studies that use micro data), economic variables such as wages or income, and financial variables such as interest rates. ${ }^{4}$ The demographic and income variables tend to be significant in nearly all estimations, while the financial variables' significance varies depending on the sample and specification. This is probably the most reliable stylized fact to come out of the empirical literature on the causes of remittances. While most papers have found evidence consistent with altruistic behavior, only a few papers such as Lucas and Stark (1985) and Agarwal and Horowitz (2002) have tested altruism against alternate family arrangements. Lucas and Stark find evidence in favor of self-interested behavior in Botswana, while Agarwal and Horowitz find evidence in favor of altruism in Guyana.

The literature on the causes of remittances has found consistent evidence supporting the notion that family ties based on altruism motivate much of the remitting that occurs. Altruism in this context is the immigrant's concern over the income or consumption levels of the family members left behind in the source country. Some studies also support the role of remittances as capital flows. But there have been no studies that have provided a clear test of whether remittances behave like other capital flows.

\section{A Framework for Analyzing Remittances}

Our immediate goal is to construct a simple model of remittances that produces a test that can differentiate between whether remittances function as capital flows or whether they serve another economic purpose. But we are also interested in developing a framework that allows for future additions or modifications, so that we can apply this framework to the further questions raised by this inquiry. Accordingly, we develop a model that motivates remittances through altruism, but which can be easily modified in order to include other motivations. In addition, this framework can be used to pursue further questions regarding remittances, such as their effects on the economy. Also, while our model assumes that the decision to migrate has already been made, this could be added as an initial stage by researchers who wish to model both the migration and remittance decisions.

We envision a country made up of a large number of identical two-person families in which one of the members has migrated and is earning an exogenous income in the foreign country. We refer to this person as the immigrant, and identify her with the subscript $I$. The family member who remains in the home country, whom we refer to as the recipient and associate with the subscript $R$, works in the domestic labor market. Assume that the recipient's income is $w_{R}=w_{L}$ with probability $p$ and $w_{R}=w_{H}$ with probability $1-p$, where $w_{L}<w_{H} \cdot{ }^{5}$ However, higher effort by the recipient reduces the probability $p$ of low output occurring. We will assume that the probability $p(e)$ is a convex function, such that $p^{\prime}(e)<0$ and $p^{\prime \prime}(e)>0$.

\footnotetext{
${ }^{4}$ See, for example, Swamy (1981), Banerjee (1984), Glytsos (1988), El-Sakka and McNabb (1999).

${ }^{5}$ One possible scenario is a labor market with moral hazard; another is when the recipient is selfemployed.
} 
The activities we model take place during a single period, but in the following order. First, the immigrant commits to a transfer function given the recipient's potential labor earnings, the recipient then decides on the effort level, finally nature plays and the outcome is realized.

The immigrant chooses a transfer and remits it to the recipient. The immigrant would like to do this because she is altruistic toward her relative. Thus the immigrant's utility, $U_{I}$, depends on the recipient's utility, $U_{R}$ :

$$
E U_{I}=u\left(c_{I}\right)+\beta E U_{R},
$$

where $c_{I}=y_{I}-t$ is the immigrant's net consumption, $y_{I}$ is her (exogenous) income, and $t$ is the transfer (or other transfer) to her relative. If $y_{I}$ is small, the equilibrium transfer is zero. As $y_{I}$ grows, at some point the immigrant can increase her expected utility by consuming one dollar less herself and transferring that dollar to her relative, thereby receiving the value of the relative's marginal utility, discounted by $\beta$. We focus on the case where transfers are operative, and thus assume $y_{I}$ is sufficiently large that $t>0$ in equilibrium. The timing of transfers is such that $t$ is given before the state of nature is revealed. ${ }^{6}$ Note that the immigrant neither knows nor directly observes the relative's effort level. ${ }^{7}$ This lack of observability of the relative's effort level gives rise to a moral hazard problem between the immigrant and the relative.

The next step is that the recipient chooses a level of effort to expend on the job. The relative's expected income reflects the effort level and the state of nature such that:

$$
E w_{R}=p w_{L}+(1-p) w_{H} .
$$

His budget constraint is

$$
c_{R}=w_{R}+t\left(w_{R}\right)
$$

Expected utility to the recipient-worker is given by

$$
E U_{R}=p(e) u_{R}\left(w_{L}+t\right)+(1-p(e)) u_{R}\left(w_{H}+t\right)-v(e) .
$$

Let $u_{R L} \equiv u_{R}\left(w_{L}+t\right)$ and $u_{R H} \equiv u_{R}\left(w_{H}+t\right)$. We assume $u_{R}$ is strictly increasing, concave, and twice continuously differentiable. The disutility of effort, $v$, is an increasing, strictly differentiable convex function. Once effort is chosen, outcome is realized, and, finally, wages are paid according to the labor contract.

Before we move on to examine the implications of this model, we point out how the basic structure can be modified or expanded in useful ways. Note that in this model, income in the recipient's country is uncertain, which reflects higher risk and possibly inefficiencies in information or production, relative to the host

\footnotetext{
${ }^{6}$ Relaxing this assumption would only strengthen our results, since allowing an altruistic immigrant to observe output and hence wages before committing to a transfer would yield a transfer that provides the relative the same consumption across both states of nature, i.e., full insurance (see Chami, 1996).

${ }^{7}$ We could, alternatively, allow for state-contingent transfers, but they do not affect the present analysis (see Chami, 1998).
} 
country. Such differences serve as the motivation for migrating, and could be elaborated on in a model that explicitly includes the migration decision. In addition, we model the recipient as expending effort in the labor market in a way that affects his income. Alternatively, we could model the recipient as expending effort (and income) on investment projects that have uncertain returns. Finally, we motivate remittances through altruism on the part of the immigrant, but other motivations based on exchange can be added to or substituted for altruism. Adding an exchangebased motivation requires that the recipient expend effort on looking after the interests of the immigrant as well as the recipient's own interests, which is easily accommodated in this structure.

\section{Solving for Effort, Transfers, and Wages}

The model is solved using backward induction, so we first examine the worker's choice of effort. The optimal level of effort is given by the first-order condition:

$$
\left(u_{R L}-u_{R H}\right) p^{\prime}-v^{\prime}=0
$$

Thus $e^{*}=e^{*}\left(b, w_{L}, w_{H}\right)$. Using the fact that $u_{R H}>u_{R L}$ so $u_{R H}^{\prime}<u_{R L}^{\prime}$, we have $e_{t}^{*}<0, e_{R L}^{*}<0$, and $e_{R H}^{*}>0.8$ These conditions say that transfers, through an income effect, reduce effort. On the other hand, raising the benefits of high output (that is, the wage paid plus transfer received), or reducing the benefits of low output increase effort. It is important to note that the change in the recipient-worker's equilibrium effort for a small change in income is the same whether income is in the form of wages or transfers: in taking derivatives with respect to $e^{*}$, one can show that $\frac{\partial e^{*}}{\partial t}=\frac{\partial e^{*}}{\partial w_{L}}+\frac{\partial e^{*}}{\partial w_{H}}$, so that an increase in the transfer is equivalent to an increase in wages in both states of nature. Given this equivalence, it is clear why the recipient reduces effort when remittances increase: remittances are a substitute for labor income. The moral hazard problem arises in this model when the relative takes advantage of the immigrant by making this substitution, or in other words by using remittances to purchase a reduction in labor effort.

Next comes the solution for remittances. The first-order condition for the immigrant is

$$
\frac{\partial E U_{l}}{\partial t}=-u_{l}^{\prime}+\beta\left[p(e) u_{R L}^{\prime}+(1-p(e)) u_{R H}^{\prime}\right]+\beta\left\{\left[u_{R L}-u_{R H}\right] p^{\prime}-v^{\prime}(e)\right\} \frac{\partial e^{*}}{\partial t} .
$$

This expression is composed of three parts: $-u_{I}^{\prime}$, the decrease in the utility of consumption because of additional transfers; $\beta\left[p u_{R L}^{\prime}+(1-p) u_{R H}^{\prime}\right]$, which is the direct effect of the relative's utility on his immigrant's utility, and is positive; and $\beta\left\{\left[u_{R L}+u_{R H}\right] p^{\prime}-v^{\prime}(e)\right\} \partial e^{*} / \partial t$, which reflects the effect of the moral hazard problem between the immigrant and the relative. In this last term, higher transfers allows the relative to exploit the immigrant more by lowering his effort (recall that

${ }^{8}$ The derivation is provided in the Appendix. 
$e_{t}^{*}<0$ ), which in turn increases the probability of the low-output state. However, the term in braces is nothing more than the first-order condition for the relative (equation 2), and hence is zero in equilibrium; holding wages constant, the immigrant completely internalizes the effect that the transfer has on the relative's labor supply. Equation (2) reflects the fact that, at the margin, the immigrant is an altruist, and transfers are compensatory in nature. ${ }^{9}$ Solving (2) implicitly for $t^{*}$, we find that $t^{*}=t\left(w_{L}, w_{H}, e^{*}, \beta\right)$, where $\frac{\partial t^{*}}{\partial w_{H}}<0, \frac{\partial t^{*}}{\partial w_{L}}<0$, while $\frac{\partial t^{*}}{\partial B}>0 .{ }^{10}$

The immigrant's reaction to changes in the relative's wage income illustrates that the immigrant intends for remittances to protect the recipient-worker against negative income shocks. This is a function of the compensatory nature of altruistically-motivated transfers. ${ }^{11}$ Thus, from the perspective of the immigrant as well, remittances are non-market substitutes for wages. But the immigrant intends for the remittances to be used only in case of a bad realization of output, not to enable the recipient to reduce her labor effort. However, the relative knows that at the margin the immigrant behaves as an altruist, which induces the relative to lower his effort. However, despite the altruism of the immigrant, the moral hazard problem persists. The immigrant and the relative do not see eye to eye, even though both understand that remittances are a substitute for market wages. ${ }^{12}$

\section{Implications for the Causes and Effects of Remittances}

The above discussion of the model points to one main implication regarding the causes of remittances. The optimal remittance function shows that remittances are compensatory in nature, rising with the level of altruism and falling as the recipient's wages rise. Thus, there should be a negative relationship between measures of the recipients' income and the level of remittances. This relationship is the opposite of what an exchange-motivated model of remittances would imply (see Lucas and Stark, 1985; Cox, 1987; and Bernheim and others, 1985). In addition, this is also the opposite relationship from what one would expect if remittances functioned as investment flows.

\section{Model Extensions and Implications}

In this section we discuss further extensions and modifications to the model, so as to accommodate other issues that have arisen in the literature on private incomes transfers in general, and to test the robustness of our theoretical predictions.

\footnotetext{
${ }^{9}$ Note that despite the altruism of the immigrant, the moral hazard problem persists. This is because the relative knows that at the margin the immigrant behaves as an altruist. This induces the relative to lower his effort.

${ }^{10}$ The derivation of these expressions is shown in the Appendix.

${ }^{11}$ The result, that altruistic transfers are compensatory in nature, is well established in the literature. See, for example, Becker (1991), Cox (1987), among others.

${ }^{12}$ Timing the remittances so that they occur after output is realized will not solve this problem and in fact will exacerbate it. This is discussed in more detail below.
} 
One issue is whether our theoretical results hinge on our assumption of asymmetry in altruism that is present in our model. For example, one issue concerns the impact of mutual caring or symmetric altruism, that is, the effect of remittances on effort if the recipient shared the remitter's altruism. Stark (1989), in the presence of perfect and complete information, and in the absence of market considerations, shows that unless mutual altruism is high and symmetric, the more selfish individual will continue to free ride on the more altruistic benefactor. In this case, Bernheim and Stark (1988) show that the altruist cannot even credibly commit to a punishment strategy, and as a result, a moral hazard problem is present, even in the absence of informational problems. In our case, this implies that remittances will continue to have negative effect on effort. Chami and Fischer (1996), in a model where informational asymmetry between the players is present, but in the context of insurance markets, show similar results. That is, unless altruism is mutual, and high enough, such that each individual values the other's utility as much as they value their own, moral hazard will continue to exist, leading to lower effort and adverse insurance market reaction. Moreover, when the incomes of the recipient and remitter are not identical, in particular, if the remitter's income is higher than that of the recipient - as it has to be the case for transfers to be positive-symmetric altruism that is high is not enough to reduce the moral hazard problem, a point made by Chami and Fullenkamp (2002).

Another extension would consider the case of merit goods, that is, when the remitter cares about certain actions that he would like the recipient to undertake, such as higher effort, $U_{I}\left(c_{I}, u_{R}, e_{R}\right)$. Work by Becker (1991), Chami (1998), and Mulligan and Philipson (1999) shows that the moral hazard problem is reduced somewhat, but at the margin the benefactor continues to be an altruist and, as a result, the remittances are still compensatory and as a result will continue to reduce effort.

A further consideration is the timing of moves adopted in our model. The model assumes remittances are chosen before the outcome is observed. A natural question arises as to how would our results change should remittances follow outcome realization. Bruce and Waldman (1990), in the presence of perfect and complete information, show that delaying transfers would only lead to Buchanan's (1975) well known "Samaritan's Dilemma," where the recipient would overconsume in the early stage and thus induce a higher transfer from the altruistic benefactor. Chami (1996), in a model with asymmetric information, shows that indeed, effort will be lower in the case where transfers are delayed, than in the case where the transfers are committed beforehand. In this case, having the "last word" does not guarantee that the recipient's effort will be higher than in the case where the immigrant precommits to the transfer scheme. Hendrik (2000) shows that precommitting to such transfers is also welfare enhancing.

Finally, an important concern is how would our results change if such remittances were not altruistically motivated, but were a result of co-insurance arrangements among the family members? Arnott and Stiglitz (1991) consider a model with mutual co-insurance arrangements among individuals in the context of insurance markets characterized by moral hazard problems. When informational asymmetries exist between partners, they show that such nonmarket co-insurance 
arrangements lead to lower effort by each recipient. The problem again is the inability of each individual to verify the level of effort exerted by the recipient of aid. They propose "peer monitoring" as the solution to the problem.

\section{Data and Estimation}

Despite the large interest in immigrant remittances, empirical investigations have tended to be limited by data problems. Simply gathering accurate data on remittances is extremely difficult because many remittances are not channeled through the payment system and therefore do not appear in the official statistics on remittances. Thus, remittances tend to be studied one country or one migrant group at a time, for which reasonable data are available. That is, one paper studies, say, the causes of the remittances of Turkish guest workers living in Germany, and another studies the causes of remittances sent to Pakistani families. The results, predictably, are quite variable across studies, which hinders general inference.

In order to test the implications of our model, we collected a panel of aggregate data on remittances from the World Bank's World Development Indicators database. The entire data set includes 113 countries for which worker remittances are reported over the 1970-1998 period. It should be noted, however, that the number of countries for which there exist no less than 10 years of continuous observations is fewer than 50. Only eight countries have remittances data available over the entire period. For the majority of countries, data are available only from the mid1980s. Even then, the continuity of the data is not assured. For several countries, missing data are common. But spanning 113 countries over the period 1970-1998, this data set is the most comprehensive one we are aware of in the remittances literature. Figure 1 shows the number of countries with data for selected subperiods.

In Table 1 and Figure 2, we present some general trends in remittances. The striking element is the rapid increase in worker remittances starting in the early 1990s following a decade of near stagnation. The observed increase could be explained by a real rise in remittances due to rising numbers of migrants around the world. But technological developments in the banking industry have also reduced the costs and increased the geographical reach over which transfers can be sent through financial institutions. This could mean that transactions that previously went unrecorded were brought into the formal banking system during this time, and therefore included in the official statistics. Since 1997, worker remittances have declined sharply, mostly in low-income countries. For middle-income countries, the level of remittances remained around $\$ 30$ billion.

In addition to data on remittances, we also collected data on per capita GDP from the PennWorld tables. Other variables used in the estimation are gross domestic investment, inflation, education enrollment, and net private capital flows, which are taken from the World Economic Outlook(WEO). In Tables 2 and 3 we present country-by-country indicators of the importance of worker remittances, constructed using the data on remittances and aggregate measures of income. In Table 2, worker remittances as a fraction of GDP are reported in descending order. In several countries, remittances account for more than 15 percent of GDP. In Table 3 , remittances are reported as a percentage of exports of goods and nonfactor 
Figure 1. Number of Countries with Data Available over the Specified Range

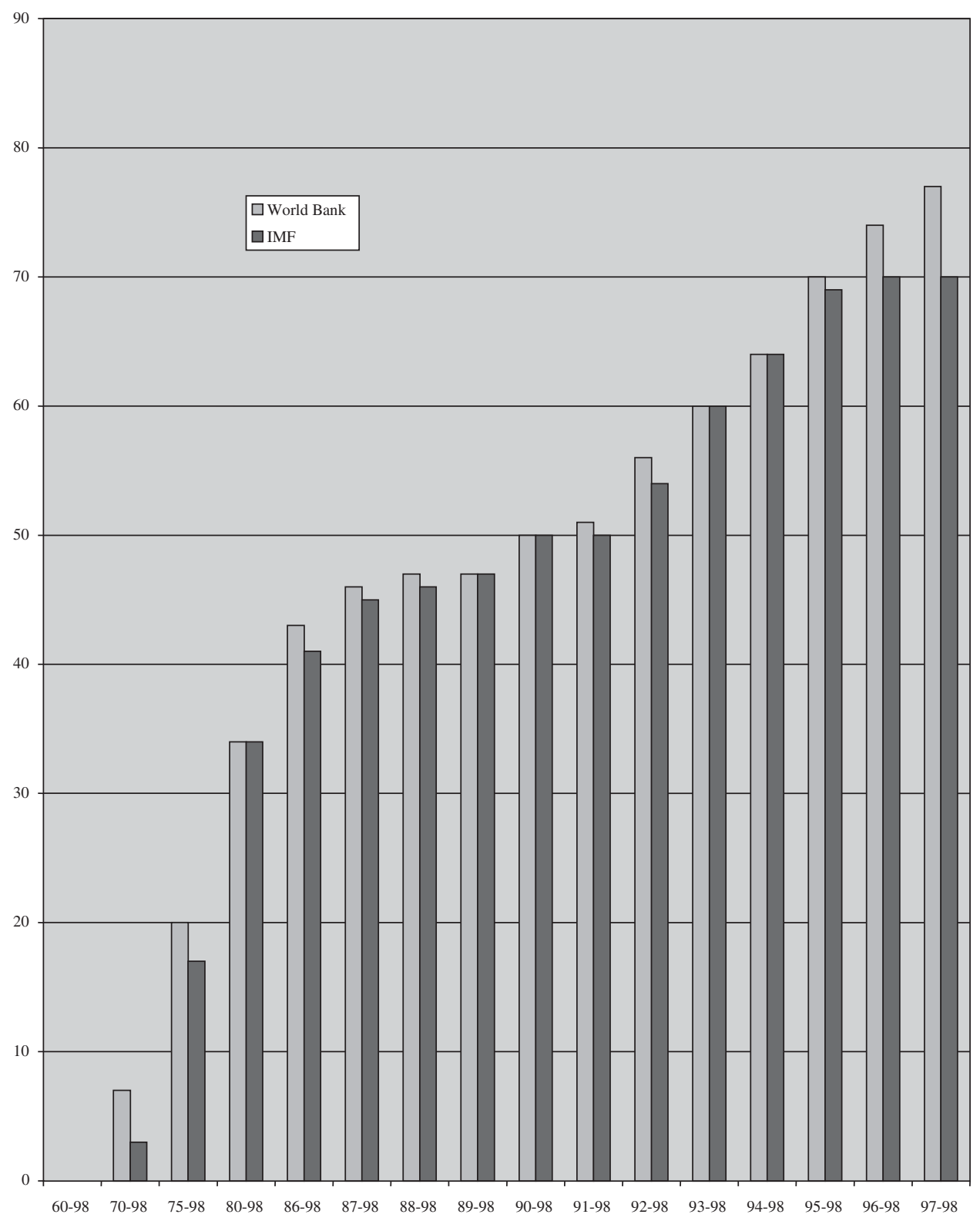

Source: World Bank and IMF. 
Ralph Chami, Connel Fullenkamp, and Samir Jahjah

Table 1. Worker Remittances

(In millions of U.S. dollars, 1970-98)

\begin{tabular}{lccccccc} 
& $1970-74$ & $1975-79$ & $1980-84$ & $1985-89$ & $1990-94$ & $1995-98$ & 1998 \\
\hline Worker remittances & 1,456 & 11,958 & 23,352 & 27,549 & 42,967 & 59,402 & 56,005 \\
Source: World Bank. & & & & & &
\end{tabular}

\section{Figure 2. Worker Remittances by Region and Country Types}
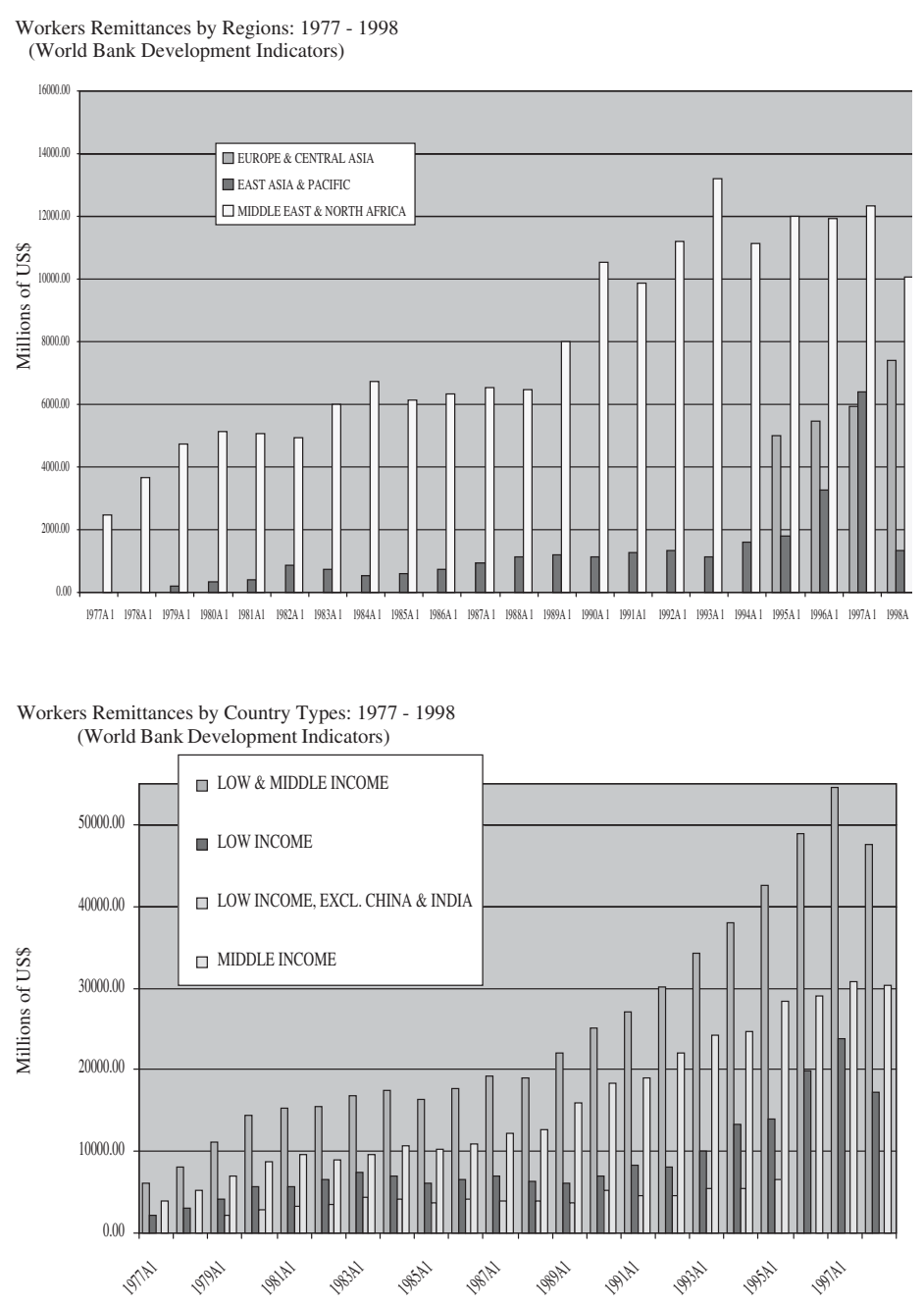


\begin{tabular}{|c|c|c|c|c|c|}
\hline \multicolumn{6}{|c|}{$\begin{array}{l}\text { Table 2. List of Countries and Worker Remittances } \\
\text { (In percent of GDP, 1970-98) }\end{array}$} \\
\hline & Mean & Maximum & Minimum & Std. Dev. & Observations \\
\hline Lebanon & 34.8 & 64.0 & 17.3 & 17.7 & 9 \\
\hline Samoa & 23.9 & 35.7 & 12.4 & 6.2 & 21 \\
\hline Eritrea & 23.2 & 32.6 & 17.6 & 5.2 & 7 \\
\hline Yemen, Rep. & 23.1 & 32.1 & 17.6 & 5.1 & 9 \\
\hline Tonga & 18.9 & 32.3 & 11.8 & 6.3 & 15 \\
\hline Albania & 16.8 & 22.4 & 11.6 & 4.0 & 7 \\
\hline Cape Verde & 16.7 & 21.2 & 12.5 & 3.1 & 13 \\
\hline Jordan & 16.2 & 24.0 & 2.1 & 6.9 & 29 \\
\hline Dominica & 8.1 & 19.6 & 3.8 & 4.3 & 23 \\
\hline Kiribati & 7.6 & 10.1 & 5.4 & 1.4 & 10 \\
\hline Egypt & 7.2 & 13.5 & 0.3 & 4.0 & 29 \\
\hline St. Vincent and the Grenadines & 7.0 & 9.1 & 5.8 & 1.2 & 10 \\
\hline Portugal & 6.8 & 10.6 & 3.0 & 2.4 & 24 \\
\hline Morocco & 6.5 & 8.5 & 5.3 & 0.9 & 24 \\
\hline Burkina Faso & 6.4 & 10.3 & 3.4 & 1.9 & 25 \\
\hline Haiti & 6.0 & 8.6 & 3.1 & 1.7 & 19 \\
\hline St. Kitts and Nevis & 6.0 & 12.0 & 1.4 & 3.8 & 15 \\
\hline El Salvador & 5.9 & 12.0 & 0.3 & 4.2 & 22 \\
\hline Grenada & 5.6 & 7.2 & 3.9 & 1.3 & 13 \\
\hline Vanuatu & 4.7 & 8.5 & 2.5 & 1.6 & 15 \\
\hline Sri Lanka & 4.5 & 6.4 & 0.2 & 2.0 & 24 \\
\hline Pakistan & 4.5 & 10.1 & 0.7 & 2.7 & 29 \\
\hline Benin & 4.5 & 8.0 & 1.3 & 1.4 & 24 \\
\hline Somalia & 4.4 & 9.5 & 1.0 & 3.4 & 5 \\
\hline Jamaica & 4.4 & 12.0 & 1.0 & 3.8 & 23 \\
\hline St. Lucia & 4.3 & 7.4 & 2.8 & 1.5 & 11 \\
\hline Nicaragua & 4.3 & 9.4 & 0.5 & 3.2 & 7 \\
\hline Belize & 4.3 & 9.9 & 2.1 & 2.4 & 15 \\
\hline Comoros & 4.2 & 8.2 & 1.1 & 2.1 & 19 \\
\hline Tunisia & 3.9 & 4.9 & 3.1 & 0.5 & 23 \\
\hline Antigua and Barbuda & 3.9 & 15.2 & 1.6 & 3.9 & 11 \\
\hline Dominican Republic & 3.8 & 8.4 & 0.8 & 2.2 & 29 \\
\hline Mali & 3.7 & 5.9 & 1.9 & 0.9 & 23 \\
\hline Sudan & 2.7 & 4.8 & 1.0 & 1.1 & 17 \\
\hline Croatia & 2.5 & 3.0 & 2.0 & 0.4 & 6 \\
\hline Greece & 2.4 & 2.8 & 1.9 & 0.3 & 22 \\
\hline Turkey & 2.4 & 3.8 & 1.5 & 0.6 & 25 \\
\hline Bangladesh & 2.2 & 3.6 & 0.0 & 1.1 & 24 \\
\hline Honduras & 2.1 & 4.1 & 0.7 & 1.1 & 12 \\
\hline Senegal & 1.9 & 2.6 & 0.5 & 0.4 & 24 \\
\hline Barbados & 1.9 & 2.7 & 1.2 & 0.5 & 12 \\
\hline Malta & 1.9 & 5.7 & 0.1 & 1.6 & 28 \\
\hline São Tomã and Príncipe & 1.8 & 10.0 & 0.0 & 2.7 & 13 \\
\hline Guatemala & 1.8 & 2.4 & 0.5 & 0.7 & 11 \\
\hline Nepal & 1.7 & 2.4 & 1.1 & 0.3 & 24 \\
\hline Seychelles & 1.5 & 2.4 & 1.0 & 0.5 & 9 \\
\hline Algeria & 1.3 & 3.1 & 0.5 & 0.8 & 22 \\
\hline
\end{tabular}


Ralph Chami, Connel Fullenkamp, and Samir Jahjah

Table 2. (Continued)

\begin{tabular}{|c|c|c|c|c|c|}
\hline & Mean & Maximum & Minimum & Std. Dev. & Observations \\
\hline Cyprus & 1.3 & 1.8 & 0.9 & 0.3 & 13 \\
\hline Costa Rica & 1.2 & 1.3 & 1.1 & 0.1 & 4 \\
\hline Togo & 1.2 & 2.0 & 0.7 & 0.5 & 21 \\
\hline India & 1.1 & 2.9 & 0.1 & 0.7 & 29 \\
\hline Nigeria & 1.0 & 5.3 & 0.0 & 1.6 & 22 \\
\hline Mexico & 0.9 & 1.4 & 0.3 & 0.3 & 19 \\
\hline New Zealand & 0.7 & 1.0 & 0.2 & 0.2 & 20 \\
\hline Guinea-Bissau & 0.7 & 0.9 & 0.4 & 0.2 & 5 \\
\hline Philippines & 0.6 & 1.3 & 0.2 & 0.2 & 22 \\
\hline Peru & 0.6 & 0.7 & 0.4 & 0.1 & 9 \\
\hline Spain & 0.6 & 0.9 & 0.3 & 0.2 & 24 \\
\hline Mauritania & 0.6 & 4.2 & 0.1 & 0.8 & 24 \\
\hline Poland & 0.6 & 0.6 & 0.5 & 0.0 & 5 \\
\hline Armenia & 0.5 & 0.7 & 0.4 & 0.1 & 4 \\
\hline Colombia & 0.5 & 1.8 & 0.1 & 0.5 & 29 \\
\hline Oman & 0.5 & 1.1 & 0.2 & 0.2 & 20 \\
\hline Cameroon & 0.4 & 0.8 & 0.1 & 0.2 & 19 \\
\hline Niger & 0.4 & 0.9 & 0.1 & 0.2 & 22 \\
\hline Cambodia & 0.4 & 0.5 & 0.3 & 0.1 & 7 \\
\hline Belgium & 0.4 & 0.5 & 0.0 & 0.2 & 24 \\
\hline Djibouti & 0.3 & 0.3 & 0.2 & 0.1 & 4 \\
\hline Namibia & 0.3 & 0.3 & 0.2 & 0.0 & 9 \\
\hline Slovenia & 0.3 & 0.4 & 0.1 & 0.1 & 7 \\
\hline Italy & 0.3 & 0.5 & 0.0 & 0.2 & 29 \\
\hline Austria & 0.2 & 0.4 & 0.1 & 0.1 & 22 \\
\hline Aruba & 0.2 & 0.3 & 0.2 & 0.1 & 4 \\
\hline Panama & 0.2 & 0.4 & 0.0 & 0.1 & 18 \\
\hline Indonesia & 0.2 & 0.8 & 0.0 & 0.2 & 16 \\
\hline Congo, Dem. Rep. & 0.2 & 0.3 & 0.1 & 0.1 & 8 \\
\hline Guinea & 0.2 & 1.1 & 0.0 & 0.4 & 8 \\
\hline Madagascar & 0.2 & 0.4 & 0.0 & 0.1 & 19 \\
\hline Trinidad and Tobago & 0.2 & 0.7 & 0.0 & 0.2 & 24 \\
\hline Belarus & 0.2 & 0.2 & 0.1 & 0.0 & 4 \\
\hline Ghana & 0.1 & 0.4 & 0.0 & 0.1 & 20 \\
\hline Korea, Rep. & 0.1 & 0.3 & 0.0 & 0.1 & 19 \\
\hline Zimbabwe & 0.1 & 0.3 & 0.0 & 0.1 & 6 \\
\hline Brazil & 0.1 & 0.4 & 0.0 & 0.1 & 20 \\
\hline Rwanda & 0.1 & 0.3 & 0.0 & 0.1 & 19 \\
\hline Moldova & 0.1 & 0.2 & 0.0 & 0.1 & 4 \\
\hline China & 0.1 & 0.5 & 0.0 & 0.1 & 17 \\
\hline Paraguay & 0.1 & 0.7 & 0.0 & 0.2 & 8 \\
\hline Lesotho & 0.1 & 0.1 & 0.1 & 0.0 & 4 \\
\hline France & 0.1 & 0.1 & 0.0 & 0.0 & 24 \\
\hline Suriname & 0.1 & 0.2 & 0.0 & 0.1 & 4 \\
\hline Kyrgyz Republic & 0.1 & 0.1 & 0.0 & 0.1 & 6 \\
\hline Switzerland & 0.1 & 0.1 & 0.1 & 0.0 & 17 \\
\hline Bolivia & 0.1 & 0.7 & 0.0 & 0.2 & 18 \\
\hline Chad & 0.0 & 0.1 & 0.0 & 0.0 & 8 \\
\hline
\end{tabular}




\begin{tabular}{|c|c|c|c|c|c|}
\hline & \multicolumn{5}{|c|}{ Table 2. (Concluded) } \\
\hline & Mean & Maximum & Minimum & Std. Dev. & Observations \\
\hline Sweden & 0.0 & 0.1 & 0.0 & 0.0 & 12 \\
\hline Hungary & 0.0 & 0.1 & 0.0 & 0.0 & 4 \\
\hline Argentina & 0.0 & 0.0 & 0.0 & 0.0 & 6 \\
\hline Norway & 0.0 & 0.0 & 0.0 & 0.0 & 15 \\
\hline Lithuania & 0.0 & 0.0 & 0.0 & 0.0 & 6 \\
\hline Romania & 0.0 & 0.0 & 0.0 & 0.0 & 5 \\
\hline Gabon & 0.0 & 0.0 & 0.0 & 0.0 & 11 \\
\hline Estonia & 0.0 & 0.0 & 0.0 & 0.0 & 5 \\
\hline
\end{tabular}

services. For many countries, remittances are the most important source of foreign exchange.

The next step in describing our data is to examine the relationship between worker remittances and per capita GDP growth using standard cross-section as well as panel estimation. Our goal is to see what correlations exist in the data, particularly between remittances and GDP growth.

The cross section is constructed as the average over the 1970-1998 period. The estimated equation is based on

$$
\Delta y_{i}=a_{0}+a_{1} y_{0 i}+a_{2} I_{i}+a_{3} w r_{i}+e_{i},
$$

where $y$ is the log of real GDP per capita, $y_{0}$ is the initial value of $y, I$ is the $\log$ of investment to GDP ratio, and $w r$ is the log of worker remittances to GDP. An alternative to (3) is to estimate the relationship between a change in worker remittances, $\operatorname{dlog}(w r)$, and growth:

$$
\Delta y_{i}=a_{0}+a_{1} y_{0 i}+a_{2} I_{i}+a_{3} \Delta w r_{i}+e_{i} .
$$

This specification better captures the dynamic nature of private transfers, and is therefore preferred. Regional dummies are also introduced as well as other variables, such as the ratio of net private capital flows to GDP ( $n p c f)$.

The idea of estimating a panel is to provide heterogeneity in the estimated coefficients. Another advantage is to capture dynamic effects. We estimate the following specifications, with the objective of being as parsimonious as possible, first because our dataset is relatively small, and second to limit the endogeneity problem. It should be noted that including variables used in the traditional empirical literature, like education or macroeconomic instability, does not affect our results.

\section{Common slope}

$$
\Delta y_{i t}=a_{0}+a_{1} I_{i t}+a_{2} \Delta w r_{i t}+a_{3} n c p f_{i t}+e_{i t}
$$

Equation (5) is estimated with and without regional dummies. 
Table 3. List of Countries and Worker Remittances

(In percent of exports of goods and nonfactor services, 1970-98)

\begin{tabular}{|c|c|c|c|c|c|}
\hline & Mean & Maximum & Minimum & Std. Dev. & Observations \\
\hline Lebanon & 269.2 & 355.7 & 166.2 & 73.8 & 9 \\
\hline Cape Verde & 161.0 & 1103.8 & 55.2 & 218.9 & 22 \\
\hline Albania & 137.9 & 166.1 & 120.0 & 17.7 & 7 \\
\hline Eritrea & 88.0 & 115.3 & 65.8 & 20.7 & 7 \\
\hline Samoa & 80.6 & 129.9 & 34.1 & 22.5 & 22 \\
\hline Yemen, Rep. & 67.1 & 100.6 & 46.3 & 18.6 & 9 \\
\hline Tonga & 57.0 & 100.4 & 11.1 & 24.0 & 19 \\
\hline Burkina Faso & 53.7 & 101.6 & 21.8 & 19.0 & 25 \\
\hline Jordan & 41.3 & 65.7 & 14.1 & 16.6 & 29 \\
\hline Haiti & 38.1 & 55.9 & 23.6 & 9.7 & 19 \\
\hline Sudan & 37.6 & 52.6 & 13.7 & 11.7 & 17 \\
\hline Pakistan & 37.3 & 84.5 & 9.3 & 25.1 & 29 \\
\hline Bangladesh & 32.7 & 64.8 & 2.0 & 15.5 & 24 \\
\hline Egypt & 31.6 & 57.4 & 2.7 & 15.8 & 29 \\
\hline Morocco & 29.4 & 39.3 & 19.9 & 5.3 & 24 \\
\hline El Salvador & 27.8 & 70.5 & 0.9 & 22.3 & 22 \\
\hline Portugal & 27.5 & 47.2 & 9.2 & 12.3 & 24 \\
\hline Turkey & 25.6 & 68.5 & 7.8 & 19.4 & 25 \\
\hline Comoros & 24.0 & 38.4 & 7.0 & 10.1 & 19 \\
\hline Mali & 22.9 & 33.7 & 14.0 & 4.9 & 23 \\
\hline Benin & 20.1 & 41.4 & 6.4 & 8.6 & 24 \\
\hline Kiribati & 19.4 & 36.3 & 12.1 & 7.9 & 10 \\
\hline Dominica & 19.1 & 54.8 & 7.1 & 13.1 & 23 \\
\hline Somalia & 15.5 & 28.7 & 2.9 & 11.2 & 5 \\
\hline Greece & 15.2 & 19.2 & 11.1 & 2.8 & 22 \\
\hline India & 15.2 & 28.1 & 3.9 & 6.8 & 29 \\
\hline Sri Lanka & 15.1 & 22.2 & 1.4 & 6.7 & 24 \\
\hline Dominican Republic & 13.4 & 18.3 & 2.8 & 4.6 & 29 \\
\hline Grenada & 12.7 & 16.7 & 9.2 & 2.7 & 13 \\
\hline Nepal & 12.6 & 19.3 & 7.3 & 3.2 & 24 \\
\hline Nicaragua & 12.5 & 26.3 & 3.2 & 7.5 & 7 \\
\hline St. Vincent and the Grenadines & 11.8 & 13.6 & 9.9 & 1.2 & 10 \\
\hline Tunisia & 10.6 & 13.7 & 7.7 & 1.8 & 23 \\
\hline St. Kitts and Nevis & 10.3 & 21.6 & 2.5 & 6.8 & 15 \\
\hline Vanuatu & 10.3 & 17.5 & 5.6 & 3.9 & 15 \\
\hline Guatemala & 9.7 & 13.4 & 3.4 & 3.5 & 11 \\
\hline Jamaica & 7.8 & 19.5 & 2.1 & 5.7 & 23 \\
\hline Belize & 7.5 & 16.1 & 4.3 & 3.8 & 15 \\
\hline Senegal & 6.5 & 10.2 & 1.3 & 1.8 & 24 \\
\hline St. Lucia & 6.1 & 9.9 & 4.2 & 1.9 & 11 \\
\hline Guinea-Bissau & 5.9 & 9.4 & 3.5 & 2.4 & 5 \\
\hline Croatia & 5.9 & 7.7 & 3.4 & 1.6 & 6 \\
\hline Honduras & 5.6 & 9.2 & 2.9 & 1.9 & 12 \\
\hline Peru & 5.3 & 6.6 & 3.0 & 1.1 & 9 \\
\hline Algeria & 5.3 & 11.9 & 1.8 & 2.9 & 22 \\
\hline São Tomé and Príncipe & 4.7 & 22.9 & 0.1 & 6.4 & 13 \\
\hline Antigua and Barbuda & 4.7 & 18.6 & 1.8 & 4.9 & 11 \\
\hline Mexico & 4.3 & 5.5 & 3.0 & 0.9 & 19 \\
\hline Colombia & 3.6 & 9.5 & 0.6 & 2.9 & 29 \\
\hline Barbados & 3.5 & 4.8 & 2.5 & 0.7 & 12 \\
\hline Spain & 3.3 & 7.4 & 1.8 & 1.8 & 24 \\
\hline
\end{tabular}


Table 3. (Concluded)

\begin{tabular}{|c|c|c|c|c|c|}
\hline & Mean & Maximum & Minimum & Std. Dev. & Observations \\
\hline Armenia & 3.1 & 4.1 & 2.6 & 0.7 & 4 \\
\hline Togo & 3.1 & 4.6 & 1.4 & 1.1 & 21 \\
\hline Seychelles & 2.7 & 4.3 & 1.6 & 0.9 & 9 \\
\hline New Zealand & 2.7 & 3.3 & 0.5 & 0.6 & 20 \\
\hline Cyprus & 2.6 & 4.0 & 1.9 & 0.6 & 13 \\
\hline Nigeria & 2.5 & 16.0 & 0.0 & 4.5 & 22 \\
\hline Philippines & 2.5 & 4.1 & 0.6 & 0.9 & 22 \\
\hline Malta & 2.5 & 10.1 & 0.1 & 2.4 & 28 \\
\hline Costa Rica & 2.2 & 2.6 & 1.6 & 0.4 & 4 \\
\hline Poland & 2.1 & 2.2 & 1.9 & 0.1 & 5 \\
\hline Niger & 2.0 & 4.4 & 0.7 & 1.1 & 22 \\
\hline Cameroon & 1.8 & 3.3 & 0.3 & 0.8 & 19 \\
\hline Cambodia & 1.7 & 2.9 & 1.0 & 0.8 & 7 \\
\hline Brazil & 1.5 & 5.5 & 0.0 & 1.7 & 20 \\
\hline Mauritania & 1.4 & 11.7 & 0.2 & 2.3 & 24 \\
\hline Congo, Dem. Rep. & 1.3 & 2.6 & 0.3 & 0.8 & 8 \\
\hline Italy & 1.3 & 3.2 & 0.1 & 0.9 & 29 \\
\hline Rwanda & 1.1 & 3.6 & 0.2 & 0.9 & 19 \\
\hline Madagascar & 1.0 & 2.4 & 0.0 & 0.8 & 19 \\
\hline Oman & 0.9 & 1.8 & 0.5 & 0.3 & 20 \\
\hline China & 0.7 & 2.3 & 0.1 & 0.7 & 17 \\
\hline Guinea & 0.7 & 4.7 & 0.0 & 1.6 & 8 \\
\hline Indonesia & 0.7 & 1.4 & 0.1 & 0.4 & 16 \\
\hline Austria & 0.7 & 0.9 & 0.3 & 0.2 & 22 \\
\hline Djibouti & 0.7 & 0.7 & 0.6 & 0.1 & 4 \\
\hline Ghana & 0.6 & 1.6 & 0.0 & 0.5 & 20 \\
\hline Belgium & 0.6 & 1.0 & 0.0 & 0.3 & 24 \\
\hline Zimbabwe & 0.6 & 1.2 & 0.0 & 0.4 & 6 \\
\hline Namibia & 0.5 & 0.6 & 0.4 & 0.1 & 9 \\
\hline Belarus & 0.5 & 0.6 & 0.4 & 0.1 & 4 \\
\hline Slovenia & 0.4 & 0.6 & 0.2 & 0.2 & 7 \\
\hline Korea, Rep. & 0.4 & 0.7 & 0.1 & 0.2 & 19 \\
\hline Trinidad and Tobago & 0.4 & 1.5 & 0.0 & 0.5 & 24 \\
\hline Bolivia & 0.4 & 4.7 & 0.0 & 1.1 & 18 \\
\hline Lesotho & 0.4 & 0.5 & 0.3 & 0.1 & 4 \\
\hline Chad & 0.3 & 0.9 & 0.0 & 0.3 & 8 \\
\hline Paraguay & 0.3 & 1.5 & 0.1 & 0.5 & 8 \\
\hline France & 0.3 & 0.5 & 0.2 & 0.1 & 24 \\
\hline Panama & 0.3 & 0.6 & 0.0 & 0.2 & 18 \\
\hline Kyrgyz Republic & 0.3 & 0.4 & 0.1 & 0.1 & 6 \\
\hline Moldova & 0.2 & 0.3 & 0.1 & 0.1 & 4 \\
\hline Argentina & 0.2 & 0.3 & 0.1 & 0.1 & 6 \\
\hline Uganda & 0.2 & 0.2 & 0.1 & 0.0 & 2 \\
\hline Switzerland & 0.2 & 0.2 & 0.1 & 0.0 & 17 \\
\hline Aruba & 0.1 & 0.2 & 0.0 & 0.1 & 8 \\
\hline Sweden & 0.1 & 0.2 & 0.0 & 0.0 & 12 \\
\hline Hungary & 0.1 & 0.1 & 0.0 & 0.0 & 4 \\
\hline Suriname & 0.1 & 0.1 & 0.0 & 0.0 & 4 \\
\hline Romania & 0.1 & 0.1 & 0.0 & 0.0 & 5 \\
\hline Norway & 0.0 & 0.1 & 0.0 & 0.0 & 15 \\
\hline Lithuania & 0.0 & 0.0 & 0.0 & 0.0 & 6 \\
\hline Gabon & 0.0 & 0.0 & 0.0 & 0.0 & 11 \\
\hline Estonia & 0.0 & 0.0 & 0.0 & 0.0 & 5 \\
\hline
\end{tabular}

Sources: World Bank and IMF. 
One-way fixed effects

$$
\Delta y_{i t}=a_{0 i}+a_{1} I_{i t}+a_{2} \Delta w r_{i t}+a_{3} n c p f_{i t}+e_{i t}
$$

\section{Two-way fixed effects}

$$
\Delta y_{i t}=a_{0 i}+a_{i} t+a_{1} I_{i t}+a_{2} \Delta w r_{i t}+a_{3} n c p f_{i t}+e_{i t}
$$

The results of these estimations are in Tables 4 to 8, where Table 4 shows the results for using the log of worker remittances over GDP and Table 5 shows the results for using the growth rate of this variable. The main result of interest is that there is a robust negative correlation between the growth rate of immigrant remittances and per capita GDP growth. The coefficient estimates on worker remit-

Table 4. Worker Remittances and Growth: Cross-Section Estimation OLS

\begin{tabular}{|c|c|c|c|}
\hline $\begin{array}{l}\text { Dependent variables: } \\
\text { Real GDP growth }\end{array}$ & I & II & $\begin{array}{c}\text { III } \\
\text { Quadratic }\end{array}$ \\
\hline Constant & $\begin{array}{l}-0.009 \\
(-0.588)\end{array}$ & $\begin{array}{l}-0.009 \\
(-0.505)\end{array}$ & $\begin{array}{l}-0.011 \\
(-0.650)\end{array}$ \\
\hline $\log \left(y_{0}\right)$ & $\begin{array}{r}0.0004 \\
(1.213)\end{array}$ & $\begin{array}{l}0.001 * \\
(1.755)\end{array}$ & $\begin{array}{l}0.001 * * \\
(2.175)\end{array}$ \\
\hline $\log (\mathrm{I} / \mathrm{GDP})$ & $\begin{array}{l}0.014 * * * \\
(2.725)\end{array}$ & $\begin{array}{l}0.014 * * \\
(2.613)\end{array}$ & $\begin{array}{l}0.014 * * \\
(2.599)\end{array}$ \\
\hline NPCF/GDP & & $\begin{array}{c}0.056 \\
(1.425)\end{array}$ & $\begin{array}{l}0.064^{*} \\
(1.640)\end{array}$ \\
\hline WR/GDP & $\begin{array}{l}-0.006 \\
(-0.222)\end{array}$ & $\begin{array}{c}-0.039 \\
(-1.463)\end{array}$ & $\begin{array}{c}0.072 \\
(1.006)\end{array}$ \\
\hline$(\mathrm{WR} / \mathrm{GDP})^{2}$ & & & $\begin{array}{l}-0.443^{*} \\
(-1.669)\end{array}$ \\
\hline East Asia & & $\begin{array}{c}0.003 \\
(0.505)\end{array}$ & $\begin{array}{c}0.003 \\
(0.576)\end{array}$ \\
\hline Eastern Europe and Central Asia & & $\begin{array}{l}-0.016 * * * \\
(-3.317)\end{array}$ & $\begin{array}{l}-0.014 * * * \\
(-3.137)\end{array}$ \\
\hline Middle East and North Africa & & $\begin{array}{c}0.007 \\
(1.193)\end{array}$ & $\begin{array}{c}0.007 \\
(1.240)\end{array}$ \\
\hline South Asia & & $\begin{array}{l}0.005 \\
(0.630)\end{array}$ & $\begin{array}{c}0.004 \\
(0.507)\end{array}$ \\
\hline Western Europe & & $\begin{array}{l}-0.009 \\
(-1.473)\end{array}$ & $\begin{array}{c}-0.007 \\
(-1.200)\end{array}$ \\
\hline Sub-Saharan Africa & & $\begin{array}{l}-0.004 \\
(-1.108)\end{array}$ & $\begin{array}{l}-0.004 \\
(-0.97)\end{array}$ \\
\hline Number of countries & 113 & 113 & 113 \\
\hline R-squared & 0.07 & 0.25 & 0.27 \\
\hline
\end{tabular}
(In percent of GDP, 1970-98)

Note: Value of $\mathrm{t}$ statistics in parentheses; * significant at 10 percent; ** significant at 5 percent; *** significant at 1 percent. 


\section{Table 5. Worker Remittances Changes and Growth: Cross Section Estimation OLS}

(1970-98)

$\begin{array}{lcc}\text { Dependent variables: Real GDP growth } & \text { I } & \text { II } \\ \text { Constant } & 0.003 & 0.002 \\ & (0.156) & (0.105) \\ \left.\text { Log( } y_{0}\right) & 0.001 & 0.001^{* *} \\ & (1.32) & (2.101) \\ \text { Log(I/GDP) } & 0.010^{* *} & 0.011^{*} \\ & (2.056) & (1.922) \\ \text { NPCF/GDP } & & 0.057 \\ & & (1.433) \\ \text { Dlog(WR) } & -0.013 * * & -0.011^{* *} \\ & (-2.454) & (-2.036) \\ \text { East Asia } & & 0.0003 \\ & & (0.071) \\ \text { Eastern Europe and Central Asia } & & -0.014 * * * \\ & & (-2.969) \\ \text { Middle East and North Africa } & & 0.004 \\ \text { South Asia } & & (0.721) \\ \text { Western Europe } & & 0.004 \\ \text { Sub-Saharan Africa } & & (0.548) \\ \text { Number of countries } & & -0.008 \\ \text { R-squared } & & (-1.412) \\ & & -0.005\end{array}$

tances generally have at least marginal statistical significance and in some specifications the estimates are highly significant.

In Tables 6 to 8, we present panel data estimation using different specifications in order to check the robustness of the results. In general, Tables 6 to 8 present one similar set of specifications tested across different samples. Table 6 shows the results from using the full sample (1970-1998), while Table 7 shows the results for the 1985-1998 time period. Table 8 displays results when only those countries with 10 or more years of continuous data are used over the 1985-1998 period. Each of these tables contains several different sets of estimates, depending on what slope specification is used. Each estimation includes the investment to GDP and worker remittances to GDP ratios as explanatory variables. Depending on the specification, we add the ratios of net private capital flows over GDP, and inflation to see how the results are affected. In most cases, we find a negative and significant relationship between remittances and growth. Over the period 1985-98, the results are stronger and more consistent (Table 7). When restricting the sample to those 


\begin{tabular}{|c|c|c|c|c|}
\hline \multicolumn{5}{|c|}{$\begin{array}{r}\text { Table 6. Worker Remittances and } \\
\text { (1970-98) }\end{array}$} \\
\hline & I & II & III & IV \\
\hline $\begin{array}{l}\text { Dependent variables: } \\
\text { GDP per capita growth }\end{array}$ & Common slope & $\begin{array}{l}\text { Common slope } \\
\text { and regional } \\
\text { dummies }\end{array}$ & $\begin{array}{c}\text { Common slope } \\
\text { and NPCF }\end{array}$ & $\begin{array}{l}\text { 2-way } \\
\text { fixed effects }\end{array}$ \\
\hline Constant & $\begin{array}{l}-0.1050 * * * \\
(-9.269)\end{array}$ & $\begin{array}{l}-0.0932 * * * \\
(-7.345)\end{array}$ & $\begin{array}{l}-0.0979 * * * \\
(-7.810)\end{array}$ & \\
\hline LOG(I/GDP) & $\begin{array}{l}0.0384 * * * \\
(10.523)\end{array}$ & $\begin{array}{l}0.0347 * * * \\
(8.628)\end{array}$ & $\begin{array}{l}0.0360 * * * \\
(9.060)\end{array}$ & $\begin{array}{l}0.0567 * * * \\
(7.470)\end{array}$ \\
\hline $\mathrm{d} \log (\mathrm{WR} / \mathrm{GDP})$ & $\begin{array}{l}-0.0044 * \\
(-1.707)\end{array}$ & $\begin{array}{l}-0.0044^{*} \\
(-1.704)\end{array}$ & $\begin{array}{l}-0.0031 \\
(-1.213)\end{array}$ & $\begin{array}{l}-0.0050 * \\
(-1.886)\end{array}$ \\
\hline NPCF/GDP & & & $\begin{array}{l}0.0004 * \\
(1.884)\end{array}$ & \\
\hline East Asia & & $\begin{array}{l}-0.0021 \\
(-0.429)\end{array}$ & $\begin{array}{l}-0.0028 \\
(-0.572)\end{array}$ & \\
\hline Eastern Europe and Central Asi & & $\begin{array}{r}0.0117 \\
(1.373)\end{array}$ & $\begin{array}{l}0.0116 \\
(1.390)\end{array}$ & \\
\hline Middle East and North Africa & & $\begin{array}{c}0.0022 \\
(0.527)\end{array}$ & $\begin{array}{c}0.0023 \\
(0.558)\end{array}$ & \\
\hline South Asia & & $\begin{array}{l}0.0146 * * * \\
(2.975)\end{array}$ & $\begin{array}{l}0.0149 * * * \\
(3.091)\end{array}$ & \\
\hline Western Europe & & $\begin{array}{c}0.0051 \\
(1.130)\end{array}$ & $\begin{array}{c}0.0054 \\
(1.223)\end{array}$ & \\
\hline Sub-Saharan Africa & & $\begin{array}{l}-0.0108 * * * \\
(-2.962)\end{array}$ & $\begin{array}{l}-0.0094 * * * \\
(-2.593)\end{array}$ & \\
\hline Number of countries & 83 & 83 & 83 & 83 \\
\hline R-squared & 0.08 & 0.10 & 0.11 & 0.17 \\
\hline
\end{tabular}

countries with at least 10 years of continuous observation, the magnitude of the negative effect is increased (Table 8). This section reinforces the results obtained in the cross-section specification. Not only do remittances in low-growth countries tend to be higher, but also higher remittances within a country are associated with lower growth.

Another way to examine the correlation between income and remittances is to estimate a remittance-determination equation,

$$
w r_{i t}=a_{0}+a_{1}\left(y_{i}-y_{u s}\right)_{t-1}+a_{2}\left(r_{i}-r_{u s}\right)_{t}+v_{i t},
$$

where $w r$ is the log of worker remittances divided by GDP, $y$ is per capita output, and $r$ is a real deposit or money market interest rate. The estimated coefficient on the income gap variable gives more evidence for the model's implication that remittances are compensatory transfers. If this coefficient is negative, this indicates that remittances increase when income in the home country is relatively depressed. This equation was also estimated country by country. 


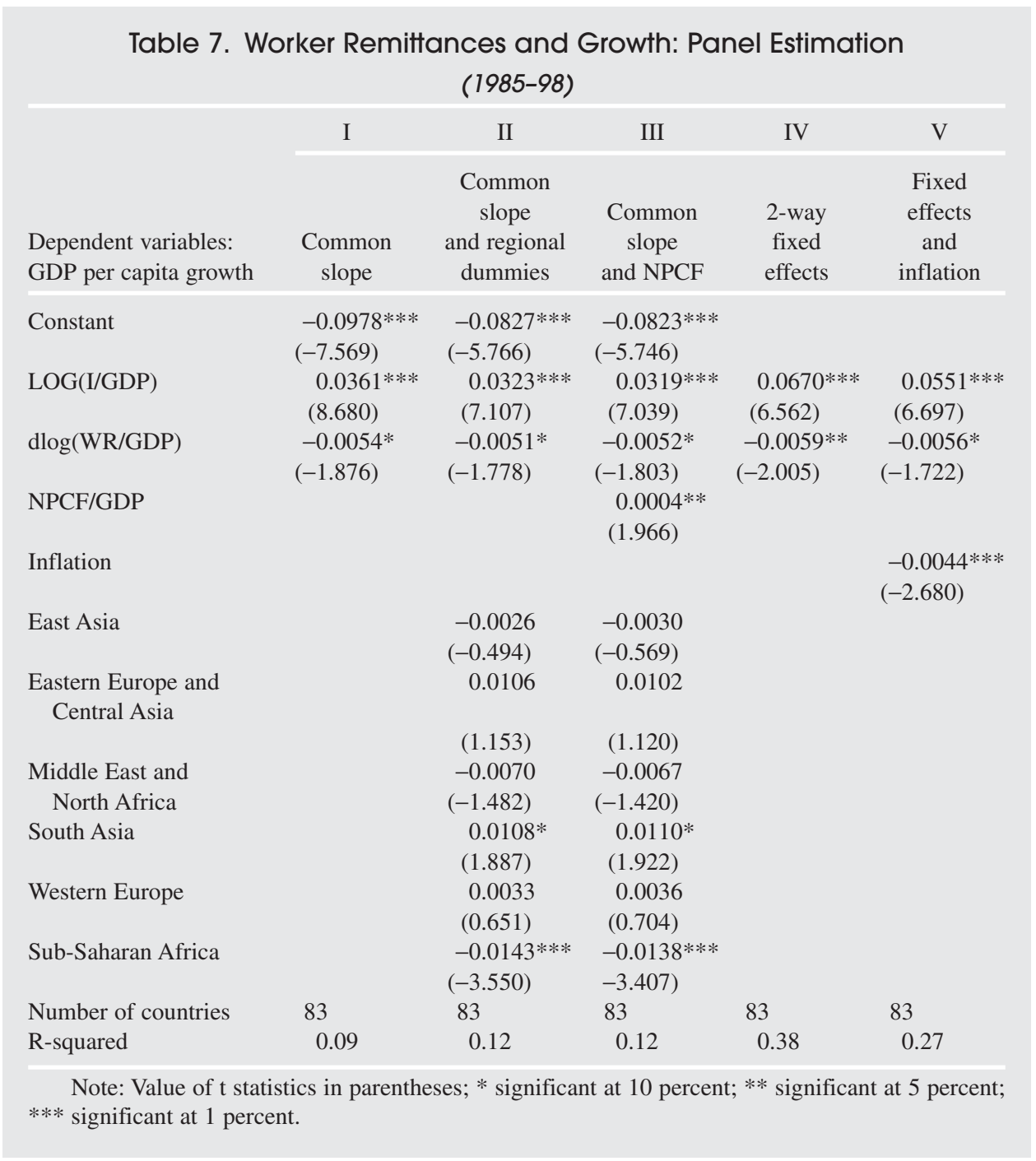

The results from this estimation are presented in Table 9. The estimated coefficient on the income gap is negative and significant, as the theory predicts. The result is also robust when the equation is estimated country by country. Of 49 countries, 29 had negative coefficients on the income gap and of these, 13 were statistically significant. Only four of the positive coefficients were significant. This evidence supports the idea that a primary function of remittances is to compensate their recipients for bad economic outcomes, such as low output.

The contrast between the negative correlation of remittances with GDP growth and the positive correlation of foreign direct investment (as part of net private capital flows) with GDP growth is strong evidence that remittances should not be considered equivalent to capital flows. Chuhan, Claessens, and Mimingi (1998), and 
Ralph Chami, Connel Fullenkamp, and Samir Jahjah

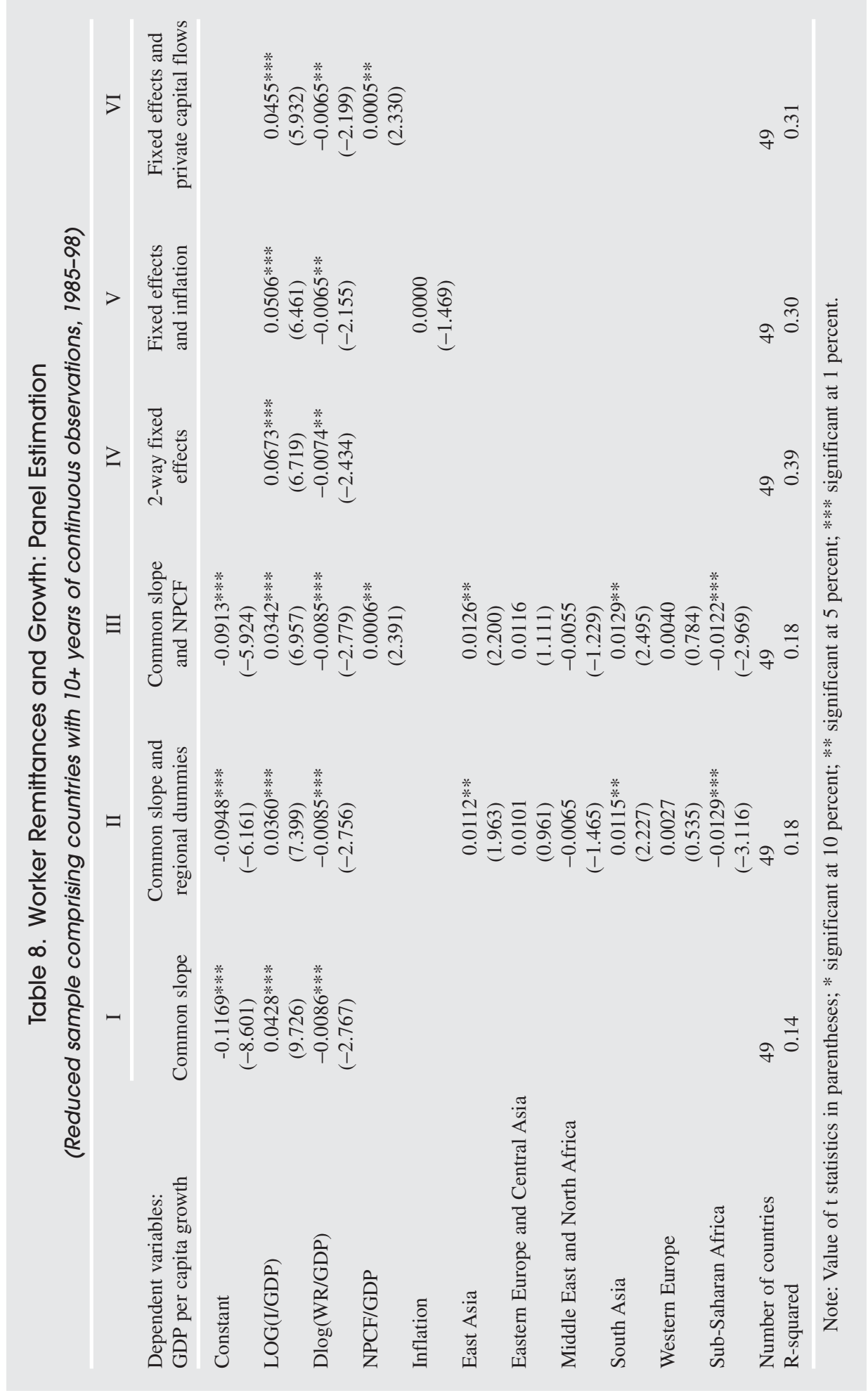




\section{Table 9. Determinants of Worker Remittances}

$\begin{array}{lc}\text { Dependent variables: Worker remittances in percent of GDP } & \text { I } \\ \text { Income gap between country } i \text { and the USA } & \text { Fixed Effects (IV: Income Gap) } \\ \text { Real interest rate gap between country } i \text { and the USA } & (-5.28) \\ \text { Number of observations } & 0.02 \\ \text { Number of countries } & -0.13 \\ \text { R-squared } & 597 \\ \quad \text { Note: } * * * \text { indicates significant at } 1 \text { percent level. } & 49 \\ \end{array}$

Sarno and Taylor (1999) find that in the case of portfolio flows, economic growth (as proxied by credit ratings, which are strongly procyclical) has a strong positive relationship with capital flows. Similarly, Ram and Zhang (2002), as well as Rajan, Siregar, and Sugema (2003) show that foreign direct investment (FDI) is positively associated with output growth during the decade of the 1990s.

\section{Conclusion}

In this paper, we have developed a model for examining the causes of remittances that yields a simple test of whether remittances behave like capital flows. Using the model, we show that altruistically motivated remittances intend to compensate their recipients for bad economic outcomes, and so should have a negative relationship with income growth. Capital flows such as FDI, on the other hand, are profit driven, and have a positive correlation with GDP growth. Our empirical estimations reveal considerable evidence that remittances tend to be negatively correlated with GDP growth, suggesting that they are compensatory in nature. We believe that this demonstrates that remittances differ greatly from private capital flows in terms of their motivation. Remittances do not appear to be intended to serve as capital for economic development, but as compensation for poor economic performance.

The negative correlation between immigrant remittances growth and per capita GDP growth is an intriguing finding. We offer this result as a stylized fact to be further investigated. The main question that our findings raise is, what are the effects of remittances on economies that receive large remittance transfers? Now that it is clear that remittances are not intended to serve as capital flows, it becomes less clear what kinds of economic impacts we should expect from them. For example, policies that are predicated on the presumption that remittances have similar uses and effects as other private capital flows may have unintended consequences. Our model points to the impact of remittances on the incentives of recipients, where remittances are used as a substitute for labor income. If these remittances are used by recipients to reduce their labor supply and labor market participation, then it is possible that economic activity will be adversely affected. 
Another concern would be the incentive effects of these remittances on governments in the recipient countries, who may view such transfers as stable source of insurance. ${ }^{13} \mathrm{~A}$ thorough analysis of the impact of these remittances on the recipient countries is outside the scope of the present paper, and is the subject of ongoing research. ${ }^{14}$

\section{APPENDIX}

Taking the differential of the first-order condition for the worker:

$$
\begin{gathered}
e_{1}^{*} \equiv \frac{\partial e^{*}}{\partial t}=-\frac{\left(u_{R L}^{\prime}-u_{R H}^{\prime}\right) p^{\prime}}{\left(u_{R L}-u_{R H}\right) p^{\prime \prime}-v^{\prime \prime}}<0 \\
e_{2}^{*} \equiv \frac{\partial e^{*}}{\partial w_{L}}=-\frac{u_{R L}^{\prime} p^{\prime}}{\left(u_{R L}-u_{R H}\right) p^{\prime \prime}-v^{\prime \prime}}<0 \\
e_{3}^{*} \equiv \frac{\partial e^{*}}{\partial w_{H}}=-\frac{-u_{R H}^{\prime} p^{\prime}}{\left(u_{R L}-u_{R H}\right) p^{\prime \prime}-v^{\prime \prime}}>0 .
\end{gathered}
$$

Writing out the second order condition for transfers gives

$$
\Delta \equiv \frac{\partial^{2} E U_{l}}{(\partial t)^{2}}=u_{l}^{\prime \prime}+\beta\left\{P^{\prime}\left(e^{*}\right)\left[u_{R L}^{\prime}-u_{R H}^{\prime}\right] e_{1}^{*}+P\left(e^{*}\right)\left[\beta u_{R L}^{\prime \prime}\right]+\left(1-P\left(e^{*}\right)\right)\left[\beta u_{R H}^{\prime \prime}\right]\right\} .
$$

Rearranging terms, we have

$$
\Delta \equiv \frac{\partial^{2} E U_{l}}{(\partial t)^{2}}=\beta P u_{R L}^{\prime}\left\{\frac{P^{\prime} e_{1}^{*}}{P}+\frac{u_{R L}^{\prime \prime}}{u_{R L}^{\prime}}\right\}-P^{\prime} e_{1}^{*} u_{R H}^{\prime}+u_{l}^{\prime \prime}+\beta(1-P) u_{R H}^{\prime \prime} .
$$

Note that all the terms save the one in braces are negative, thus a sufficient condition for the concavity of the immigrant's surplus function is:

$$
\frac{-u_{R L}^{\prime \prime}}{u_{R L}^{\prime}}>\frac{P^{\prime} e_{i}^{*}}{P}, \text { where } i=1,2 .
$$

The above assumption implies that a sufficient condition for an interior solution to the immigrant's problem is that the relative is sufficiently risk averse, such that the direct impact of a change in his wealth on his marginal utility of wealth, in the bad state, exceeds the indirect impact of wealth on the probability of a low output occurring through its effect on the relative's effort.

To sign the derivative of $t^{*}$ with respect to $\beta$, differentiate the first-order condition for the immigrant (3):

$$
\frac{d t^{*}}{d \beta}=\frac{-\left[p u_{R L}^{\prime}+(1-p) u_{R H}^{\prime}\right]}{\Delta}>0
$$

\footnotetext{
${ }^{13}$ See Barajas and others (2004).

${ }^{14}$ See Chami, Fullenkamp, and Jahjah (2003).
} 
For the derivative of $t^{*}$ with respect to $w_{H}$, we have

$$
\frac{\partial t^{*}}{\partial w_{H}}=-\frac{\beta\left[(1-p) u_{R H}^{\prime \prime}+\left(u_{R L}^{\prime}-u_{R H}\right) p^{\prime} e_{3}\right]}{\Delta}<0
$$

Finally, for the derivative of $t^{*}$ with respect to $w_{L}$, and using the sufficient condition A.1, we have

$$
\frac{\partial t^{*}}{\partial w_{L}}=-\frac{\beta\left[p u_{R L}^{\prime \prime}+\left(u_{R L}^{\prime}-u_{R H}^{\prime}\right) p^{\prime} e_{2}\right]}{\Delta}<0 .
$$

\section{REFERENCES}

Abel, Andrew, and Laurence Kotlikoff, 1988, "Does the Consumption of Different Age Groups Move Together? A New Nonparametric Test of Intergenerational Altruism," unpublished.

Agarwal, Reena, and Andrew W. Horowitz, 2002, "Are International Remittances Altruism or Insurance? Evidence from Guyana Using Multiple-Migrant Households," World Development, Vol. 30, pp. 2033-44.

Altonji, Joseph, Fumio Hayashi, and Laurence Kotlikoff, 1992, "Is the Extended Family Altruistically Linked? Direct Tests Using Micro Data," American Economic Review, Vol. 82, pp. 1177-98.

Arnott, Richard, and Joseph E. Stiglitz, 1991, "Moral Hazard and Nonmarket Institutions: Dysfunctional Crowding Out or Peer Monitoring?" American Economic Review, Vol. 81, pp. 179-89.

Banerjee, Biswajit, 1984, "The Probability, Size, and Uses of Remittances from Urban to Rural Areas in India," Journal of Development Economics, Vol. 16, pp. 293-311.

Barajas, Adolfo, Ralph Chami, Connel Fullenkamp, and Tala Khartabil, 2004, "One Reason Why One Size Doesn't Fit All: The Role of Remittances in Debt Sustainability," unpublished.

Becker, Gary, 1974, "A Theory of Social Interaction," Journal of Political Economy, Vol. 82, pp. 1063-93.

— , 1991, A Treatise on the Family, Enlarged Edition (Cambridge, Massachusetts: Harvard University Press).

Bernheim, Douglas, and Oded Stark, 1988, "Altruism Within the Family Reconsidered: Do Nice Guys Finish Last?" American Economic Review, Vol. 78, pp. 1034-45.

Bernheim, Douglas, Andre Shleifer, and Larry Summers, 1985, "The Strategic Bequest Motive," Journal of Political Economy, Vol. 93, pp. 1045-176.

Bruce, Neil, and Michael Waldman, 1990, "The Rotten Kid Theorem Meets the Samaritan's Dilemma," Quarterly Journal of Economics, Vol. 105, pp. 155-65.

Buch, Claudia M., Anja Kuckulenz, and Marie-Helene Le Manchec, 2002, "Worker Remittances and Capital Flows," Kiel Working Paper 1130, Kiel Institute for World Economics.

Buchanan, James M., 1975, “The Samaritan's Dilemma," in Altruism, Morality, and Economic Theory, ed. by Edmund S. Phelps (New York: Russell Sage Foundation), pp. 71-85.

Chami, Ralph, 1996, "King Lear's Dilemma: Precommitment versus the Last Word," Economics Letters, Vol. 52, pp. 171-76.

1998, "Private Income Transfers and Market Incentives," Economica, Vol. 65, pp. $557-80$. 
_ and Jeffrey H. Fischer, 1996, "Altruism, Matching and Nonmarket Insurance," Economic Inquiry, Vol. 34, pp. 630-47.

- and Connel Fullenkamp, 2002, "Trust and Efficiency," Journal of Banking and Finance, Vol. 26, pp. 1785-810.

, Connel Fullenkamp, and Samir Jahjah, 2003, "Are Immigrant Remittance Flows a Source of Capital for Development?” IMF Working Paper 03/189 (Washington: International Monetary Fund).

Chuhan, Punam, Stijn Claessens, and Nlandu Mimingi, 1998, "Equity and Bond Flows to Latin America and Asia: The Role of Global and Country Factors," Journal of Development Economics, Vol. 55, pp. 439-63.

Cox, Donald, 1987, "Motives for Private Income Transfers," Journal of Political Economy, Vol. 95, pp. 508-46.

El-Sakka, M. I. T., and Robert McNabb, 1999, "The Macroeconomic Determinants of Emigrant Remittances," World Development, Vol. 27, pp. 1493-502.

Elbadawi, Ibrahim A., and Robert de Rezende Rocha, 1992, "Determinants of Expatriate Workers' Remittances in North Africa and Europe," World Bank Policy Research Working Paper 1038 (Washington: World Bank).

Glytsos, Nicholas P., 1988, "Remittances in Temporary Migration: A Theoretical Model and Its Testing with the Greek-German Experience," Weltwirtschaftliches Archiv, Vol. 124, pp. 524-49.

Gubert, Flore, 2002, "Do Migrants Insure Those Who Stay Behind? Evidence from the Kayes Area (Western Mali)," Oxford Development Studies, Vol. 30, pp. 267-87.

Hendrik, Jürges, 2000, "Of Rotten Kids and Rawlasian Parents: The Optimal Timing of Intergenerational Transfers," Journal of Population Economics, Vol. 13, pp. 147-57.

Ilahi, Nadeem, and Saqib Jafarey, 1999, "Guestworker Migration, Remittances, and the Extended Family: Evidence from Pakistan," Journal of Development Economics, Vol. 58, pp. 485-512.

Johnson, G. E., and W. E. Whitelaw, 1974, "Urban-Rural Income Transfers in Kenya: An Estimated-Remittances Function," Economic Development and Cultural Change, Vol. 22, pp. 473-79.

Lucas, Robert E. B., and Oded Stark, 1985, "Motivations to Remit: Evidence from Botswana," Journal of Political Economy, Vol. 93, pp. 901-18.

Mulligan, Stacey, and Tomas J. Philipson, 1999, "Policy Design and Incidence in a Merit Good Economy," unpublished.

Poirine, Bernard, 1997, "A Theory of Remittances as an Implicit Family Loan Arrangement," World Development, Vol. 25, pp. 589-611.

Rajan, Ramkishen S., Reza Siregar, and Iman Sugema, 2003, "Why Was There a Precrisis Capital Inflow Boom in Southeast Asia?" Journal of International Development, Vol. 15, pp. 265-83.

Ram, Rati, and Kevin Honglin Zhang, 2002, "Foreign Direct Investment and Economic Growth: Evidence from Cross-Country Data for the 1990s," Economic Development and Cultural Change, Vol. 51, pp. 205-15.

Russell, Sharon Stanton, 1986, "Remittances from International Migration: A Review in Perspective," World Development, Vol. 14, pp. 677-96.

Sarno, Lucio, and Mark P. Taylor, 1999, "Hot Money, Accounting Labels and the Permanence of Capital Flows to Developing Countries: An Empirical Investigation," Journal of Development Economics, Vol. 59, pp. 337-64. 
Stark, Oded, 1989, “Altruism and the Quality of Life," AER Papers and Proceedings, Vol. 79, pp. 86-90.

— 1991, "Migration in LDCs: Risk, Remittances, and the Family," Finance and Development, December, pp. 39-41.

— and D. Bloom, 1985, "The New Economics of Labor Migration,” American Economic Review, Vol. 75, pp. 173-78.

Stark, Oded, and Robert E. B. Lucas, 1988, "Migration, Remittances and the Family," Economic Development and Cultural Change, Vol. 36, pp. 465-81.

Straubhaar, Thomas, 1986, "The Determinants of Workers' Remittances: The Case of Turkey," Weltwirtschaftliches Archiv, Vol. 122, pp. 728-40.

Swamy, Gurushri, 1981, "International Migrant Workers' Remittances: Issues and Prospects," World Bank Staff Working Paper 481 (Washington: World Bank).

Townsend, Robert M., 1994, "Risk and Insurance in Village India," Econometrica, Vol. 62, pp. 539-91.

Wahba, Sadek, 1991, "What Determines Workers' Remittances?" Finance and Development, December, pp. 41-44. 